\title{
REPOSISI KEDUDUKAN SAUDARA DALAM HUKUM WARIS ISLAM
}

\author{
Juandi \\ STIH Pertiba Pangkalpinang
}

\begin{abstract}
Islamic inheritance law makes three categories of siblings with different parts. This difference shows that the position of siblings, siblings of one father and siblings of one mother is not the same. This is understood from the explanation of the different inheritance of the brother in the Qur'an, namely verse 12 and verse 176 surah an-Nisa '. This reading leaves a problem because in reality there is no significant importance in the distinction except the attempt to reconcile the two verses. By using a systematic reading of the theme of kalalah followed by the theory of the primary and secondary heirs, it is found that the difference in the brother's part as the heir is more to the difference of his position as the primary or secondary heir, not the difference as a sibling, siblings of one father and siblings of one mother. Therefore the repositioning of sibling position in Islamic law of inheritance should be applied.
\end{abstract}

\section{Keyword: heirs, sibling, Islamic inheritance}

\section{A. Pendahuluan}

Saudara merupakan salah satu ahli waris yang diperhitungkan dalam hukum waris Islam dan dijelaskan dalam al-Qur'an. Kedudukan saudara menajadi signifikan ketika ahli waris dari golongan anak dan orang tua sudah tidak ada. Dalam kajian hukum waris, ulama fikih membuat perbedaan-perbedaan anatar saudara yang menjadi ahli waris, yaitu saudara sekandung, saudara seayah dan saudara seibu. Pembedaan ini nampaknya untuk menyelesaikan persoalan yang dinyatakan dalam alQur'an suat an-Nisa' ayat 12 dan suarat an-Nisa' ayat 176. Al-Qur'an menyebutkan bagian-bagain saudara pada dua ayat tersebut sebagai ahli waris, namun membuat penjelsan yang berbeda tentang bagian-bagiannya. 
Usaha mengkompromikan dua ketentuan hukum yang berbeda dilakukan ulama dengan metode al-jam'u, yaitu mengumpulkan kedua aturan tersebut kemudian memberikan penjelasan apakah keduanya berentangan atau masih dapat dikompromikan. ${ }^{1}$ Ketentuan ahli waris dari golongan saudara ini menghasilakan kesimpulan bahwa kedua ayat tersebut dapat dikompromikan. Hasilnya adalah adanya pembedaan katagori saudara dalam hukum waris Islam.

Apa yang disimpulkan dan kemudian diterima oleh masyarakat muslim dalam kaitan dengan kedudukan saudara dalam hukum waris Islam, kenyataanya menyisakan permaslahan. Bagi masyarakat tertentu, semisal Indonesia, tidak terlalu signifikan membedakan antara saudara sekandung, seayah atau seibu. Keluarga bilateral hanya mengenal saudara baik itu sekandung, seayah atau seibu. Diluar itu yang dikenal adalah saudara tiri. Oleh karena itu, perlu melakukan kajian ulang tentang reposisi saudara dalam hukum waris Islam dengan perspektif yang tidak diskriminatif.

Kajian ini dilakukan dengan pendekatan normatif-sosiologis dengan model pembacaan sistematis. Pembacaan sistematis yang dimaksud adalah menghubungkan antar dengan ayat untuk mendapatkan pemahaman yang komprehensif. Dalam kajian studi al-Qur'an disebut dengan munasabah ayat.

\section{B. Saudara sebagai Ahli Waris}

Persoalan kewarisan saudara yang termuat dalam ayat al-Qur'an adalah pembicaraan tentang kalalah. Makna kalalah mengandung banyak perdebatan di kalangan umat Islam, diantaranya ada yang berpendapat

1 Jika terdapat dua nash yang kontradiktif menurut arti lahirnya, maka harus diadakan pembahasan untuk memadukan keduanya dengan cara-cara memadukan yang sahih. Abdul Wahab Kholaf, Ilmu Ushul Fikih: Kaidah Hukum Islam (terj. Faiz al Muttaqin), (Jakarta: Pustaka Amani, 2003), hlm.336 
kalalah adalah ahli waris, ada juga yang berpendapat kalalah itu pewaris itu sendiri (orang yang meninggal), dan pendapat yang meyakini kedua makna tersebut. ${ }^{2}$ Diluar itu ada juga yang berpendapat kalalah sebagai menantu perempuan. ${ }^{3}$ Namun, sejauh ini makan kalalah yang lebih sesuai dengan konteks ayat-ayat al-Qur'an yang berbicara tentangnya adalah saudara laki-laki, baik ia berkedudukan sebagai pewaris maupun sebagai ahli waris. ${ }^{4}$

Makna tersebut sesungguhnya telah Allah jelaskan dalam ayat 176 surat an-Nisa'. Pertanyaan yang signifikan adalah kapan saudara memiliki hak untuk mewarisi? Dalam hubungan dengan hukum waris yang telah Allah jelaskan, saudara tidak dapat mewarisi ketika pewaris memiliki anak (walad). Al-Qur'an tidak membedakan antara anak lak-laki dan perempuan. Hal ini didasari bahwa kata walad mencakup pengertian maskulin (anak laki-laki) maupun feminim (anak perempuan), karana dalam bahasa Arab tidak dijumpai bentuk feminim pada kata al-awlad. ${ }^{5}$ Hazairin menghubungkan pengertian walad ini dengan dengan arti mawali dalam surat an-Nisa' ayat 33, sehingga menghasilkan pemahaman yang luas tentang walad, yaitu keturunan. Dalam analisanya tentang sistem kewarisan bilateral yang dicanangkan al-Qur'an, keturunan tidak dibedakan antara garis laki-laki dan perempuan. ${ }^{6}$ Dengan demikian, saudara hanya mewarisi ketika pewaris tidak memiliki keturunan sama sekali.

2 Lihat: Abu Ja'far Muhammad Ibn Jarir at-Ṭabari, Jami' al-Bayan an Ta'wil ay al-Qur'ān (Bairut: Dār al-Fikr, t.t), IV: 191-3

3 David S. Power, Studies in Qur'an and Hadis: The Formation of the Islamic Law of inheritance (Barkeley: University of California Press, 1986), hlm. 40; idem, "The Islamic Law of Inheritance Reconsidered: a New Reading of Q. 4:12B", dalam Studia Islamica No. 1-70 thn. 1953-1989 (Paris: G.P Maisonneuve-Larose, 1982), XXVIII: 83

${ }^{4}$ Juandi, "Pemahaman dan Pemaknaan Kalalah dalam Historisitas Hukum Kewarisan Islam" dalam Asy-Syari'ah: Jurnal Ilmu Syari'ah dan Perbankan Islam, Vol.1, no.1 Desember 2013 STAIN Syaikh Abdurrahman Siddik, hlm. 64

${ }^{5}$ Muhammad Syaḥrūr, Naḥw Ușul Jadidah lil Fiqh al-Islāmī Fiqh al-Mar'ah (al-Wașiyah, alIrś, al-Qawāmah, at-Ta'addadiyah, al-Libās), ( Damaskus: Al-Ahali lil-Tiba'ah Wa an-Nașr wa at-Tauzi, 2000), hlm. 234 1982), hlm. 50

${ }^{6}$ Hazairin, Hukum Kewarisan Bilateral Menurut al-Qur'an dan Hadis (Jakarta: Tintamas, 
Saudara-saudara yang mewarisi saudaranya, dalam pandangan ulama sepanjang sejarah hukum kewarisan Islam, dibedakan menjadi tiga katagori, yaitu saudara sekandung, saudara sebapak, dan saudara seibu. ${ }^{7}$ Pembedaan ini tidak lain merupakan implikasi dari pemahaman dua ayat kalalah yang membedakan bagian warisan. Ulama berkepentingan untuk menjalaskan saudara yang seperti apa yang mendapat bagian waris berimbang antara laki-laki dan perempuan. Oleh karena itu, kalalah pertama yang berbicara tentang kewarisan saudara ditafsirkan sebagai saudara seibu, ${ }^{8}$ sedangkan kalalah kedua membicarakan kewarisan saudara sekandung atau sebapak. ${ }^{9}$ Pembedaan ini sebagaimana yang sudah disebutkan sebelumnya, lebih merupakan solusi penyelesaian terhadap persoalan dua nass yang bertentangan. Metode ini disebut dengan al-Jam'u wa at-Taufiq. ${ }^{10}$

Tafsir-tafsir belakangan menganut pendapat di atas. Misalnya Sayyid Quṭb dengan tegas meyakini penafsiran ini dan kemudian memberikan argumentasi mengapa saudara seibu berbeda dalam pengaturan warisannya. Setidaknya ada tiga alasan. Pertama, mereka ---baik laki-laki maupun perempuan--- sama bagiannya dalam warisan. Kedua, mereka tidak mewarisi kecuali bila si mati dalam keadaan kalalah 'tidak mempunyai orang tua dan anak'. Dengan demikian, mereka tiak mewarisi bersama dengan ayah, kakek, anak, atau cucu dari anak laki-laki. Ketiga,

\footnotetext{
${ }^{7}$ Dalam kitab-kitab khusus membahas waris selalau ditemukan adanya sub bab yang membahas topic tersendiri tentang kewarisan saudara seibu dan saudara sekandung. Lihat: Muhammad Abu Zahrah, Ahkām at-Tirkāt wa al-Mawāris (al-Qāhirah: Dār al-Fikr al-'Arab̄i, 1963), hlm. 115-22

${ }^{8}$ Misalnya aț-Ṭabari mencatat setidaknya ada tujuh riwayat yang menyebutkan bahwa dalam qira'at Sa'ad ibn Abi waqās, kalālah pertama menyebutkan akhun au ukhtun li al-umm. Berdasarkan riwayat inilah penafsiran tentang saudara seibu terus dikembangkan. Lihat: Jami' al-Bayan an Ta'wil ay al-Qur'an (Bairut: Dar al-Fikr, t.t), VI: 194. dalam catatan lain dikatakan bahwa qira'at Ubay dengan menambah “min al-umm” sedangkan qira'at Sa'ad berbunyi min umm. Muhammad Rasyid Riḍa, Tafsīr al-Qur'an al-Hakīm al-Masyhūr bi Tafsīr al-Manār (Beirut: Dār al-Kutub al-Ilmiyah, 1999), IV: 346

${ }^{9}$ Misalnya lihat: Șadiq Hasan Khān, Fath al-Bayān fii Maqāṣid al-Qur'ān (ttp.: tnp., t.t), II: 422

${ }^{10}$ Salah satu cara melakukan jam'u wa at-taufiq adalah dengan cara menentukan jalur masingmasing dari dua hal yang berlain. Lihat: Kamal Muchtar, dkk, Ushul Fikih Jilid 1, (Jakarta: Dhana Bakti Wakaf, 1995), hlm. 180
} 
bagian mereka tidak lebih dari sepertiga, meskipun jumlah mereka banyak, baik laki-laki maupun perempuan. ${ }^{11}$ Pendapat lain dikemukakan Abu Ḥayyān. Sekalipun ia menegaskan bahwa lafaz al-akh dalam ayat kewarisan tidak dibedakan kepada saudara sekandung, seayah atau seibu karena lafaznya mutlaq, tetap menganggap ke-mutlaq-an lafaz tersebut tidak bisa digunakan karena ada hadis yang menyebutkan bahwa al-akh pada ayat 12 surat an-Nisa' adalah saudara seibu. ${ }^{12}$ Pendapat ini juga dipegang oleh Rasyid Riḍa. Sekalipun ia mengakui bahwa ayat 12 ini mengatur pembagian warisan saudara seibu, tetapi qira'at yang menunjukannya merupakan al-qira'at asy-syazah sehingga ia bukanlah qira'at tetapi hanyalah tafsir. $^{13}$

Pendapat Rasyid Riḍa tersebut dapat dijadikan pegangan untuk mengatakan bahwa penyebutan akhun atau ukhtun dalam ayat 12 hanyalah penafsiran sahabat. Al-Qur'an tidak memberikan suatu perincian tentang hubungan persaudaraan ini. Dengan tidak adanya perincian tersebut sesungguhnya selaras dengan sistem kekeluargaan bilateral menurut alQur'an, sehingga tidak ada pembedaan antara saudara sekandung, saudara sebapak atau saudara seibu. Semua jenis saudara tersebut wajib ikut diperhitungkan tanpa membeda-bedakan hubungan persaudaraan. ${ }^{14}$

Secara historis penafsiran yang membedakan antara saudara kandung dan saudara seibu sangat janggal. Ayat 176 yang dijelaskan Nabi sebagai ayat yang turun pada musim panas ${ }^{15}$ diturunkan belakangan setelah diturunkan ayat $12 .{ }^{16}$ Ayat kalālah 176, menurut satu pendapat,

\footnotetext{
${ }^{11}$ Sayyid Quțub, Fi Zhilal al-Qur'an (Beirut: Dār Ihya', 1971) IV: 268

${ }^{12}$ Muhammad Yusuf Abu Hayyān al-Andalusī, Al-Baḥr al-Muḥit, cet.ke.2 (Beirut: Dār al-Fikr, 1978), III: 185

${ }^{13}$ Rasyid Riḍa, Tafsīr al-Qur'an..., IV: 346

${ }^{14}$ Hazairin, Hukum Kewarisan Bilateral ..., hlm. 50

15 Muhammad bin Ahmad Abi Abdullah al-Anshori al- Qurțubi, Al-Jāmi' li ahkām al-Qur'ān, cet. ke-2, (ttp: Dār al-Kitāb al-'Arabi, 1967), III: 2025

16 Surat an-Nisa' ayat 12 tersebut berbunyi:
} 
merupakan ayat yang akhir turun sebagaimana surat yang akhir turun adalah surat al-Bara'ah. ${ }^{17}$ Sekalipun tidak ada data yang pasti tentang seberapa lama jarak turunnya antara ayat 12 dan ayat 176, ayat 12 diyakini turun lebih dahulu. Pertanyaan yang penting adalah mengapa pengaturan terhadap kewarisan saudara seibu lebih dulu dari pengaturan kewarisan saudara sekandung dan saudara sebapak. Kondisi ini cukup janggal karena di tanah Arab yang patrilinial justru lebih banyak menghasilkan orang yang bersaudara sekandung atau sebapak bila dibandingkan dengan saudara seibu. ${ }^{18}$ Perbedaan bagian warisan antara saudara yang disebutkan dalam ayat 12 dan 176 bukan terletak pada perbedaan jenis saudara ini tetapi karena adanya keadaan lain.

Keadaan lain yang menyebabkan terjadinya perbedaan dalam pembagaian warisan saudara ini terletak pada adanya ahli waris lain disamping saudara. Kalalah pertama mengindikasikan bahwa disamping saudara masih terdapat pasangan dari pewaris, dan mungkin juga kedua orang tua. Korelasi pertama dengan pasangan pewaris diindikasikan dengan redaksi ayat yang menyatu. Tidak ada pemisahan antara satu redaksi dengan redaksi sebelumnya, bahkan menggunakan penghubung "dan". Sedangkan hubungan saudara dengan orang tua langsung dijelaskan al-Qur'an dengan menentukan bagian Ibu secara eksplisit jika tidak ada anak dan hanya ada saudara, sedangkan bagian bapak tidak

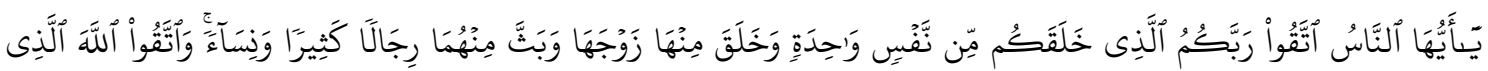

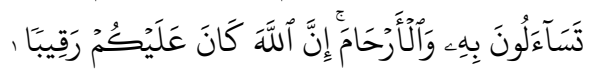

An-Nisa' ayat 176 berbunyi:

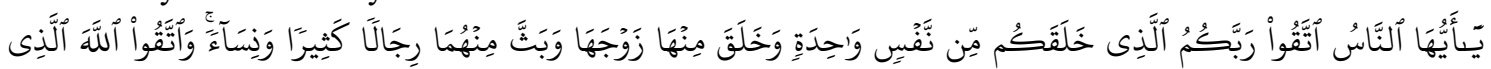

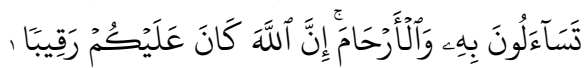

${ }^{17}$ Abī Bakr Muhammad bin Abdullah Ibn Arabi, Ahkām al-Qur'ān, tahqiq: Ali Muhammad alBajawī, (ttp.: tnp., 1967), I: 519

${ }_{18}$ Sajuti Thalib, Hukum Kewarian Islam di Indonesia, cet.ke-8 (Jakarta: Sinar Grafika, 2004), hlm. 146-7 
disebutkan. Dalam pendapat lain disebutkan bahwa "perbedaan keadaan" yang menyebabkan perbedaan saham dalam kasus kalālah pertama dan kalālah kedua terletak pada keadaan kedua orang tua. Dalam kalālah pertama, saudara-saudara (baik laki-laki maupun perempuan) menjadi żawi al- furūḍ. Dengan demikian tidak ada halangan bagi saudara tersebut untuk berkonkurensi dengan ibu yang menjadi żawi al- furūḍ dan ayah yang menjadi żawi al-qārabah (karena tidak ada anak). Dalam kalālah kedua, saudara laki-laki ditetapkan sebagai żawi al-qārabah. Keadaan mana setelah tidak ada ayah. Saudara laki-laki tidak mungkin bersama ayah menjadi żawi al-qārabah karena kelompok keutamaan ayah lebih tinggi dari saudara. ${ }^{19}$

Saudara-saudara, menurut berbagai penafsiran, tidak mendapat warisan bila terdapat Ayah. Karena Ayah dapat menghijab saudara. Dari keyakinan inilah, dipahami bahwa kalālah adalah orang yang tidak mempunyai anak dan ayah. Sementara Ibu tidak menghalangi saudara untuk mewarisi. Pendapat ini nampaknya bisa dimaklumi mengingat sistem kekeluargaan yang masih mendominasi adalah sistem kebapakan. Namun pendapat ini tidak harus kita ikuti. Karena bagaimanapun, hasil pemikiran, atau dengan kata lain peradaban Islam, yang ada selama ini hanyalah sebuah upaya memahami wahyu secara metodis dan intelektual dalam periode sejarah tertentu, dan di bawa sosiokultural tertentu pula. ${ }^{20}$ Sehingga kita akan selalu menemukan berbagai pendapat yang berbeda dalam satu persoalan sesuai dengan kapasitas intelektual seseorang dan latar belakang sosiokulturalnya. Karena masyarakat Arab masih memegang sistem kekeluargaan yang patriarkhal, wajar pendapat-pendapat seputar

${ }^{19}$ Al Yasa Abubakar, Ahli Waris Sepertalian Darah: Kajian Perbandingan Terhadap Penalaran Hazairin dan Penalaran Fikih Mazhab, (Jakarta: INIS, 1998), hlm. 48

${ }^{20}$ Issa J. Boulata, Dekonstruksi Tradisi: Gelar Pemikiran Arab Islam, alih bahasa: Imam Khoiri, cet.1 (Yogyakarta: Lkis, 2001), hlm. 58. pernyataan ini adalah pandangan Hasan Hanafi ketika membongkar Tradisi Islam dalam sketsa proyek pemikirannya di bawah judul At-Turas wa Tajdīd: Mauqifunā min at-Turaś al-Qadīm. 
persoalan hukum keluarga, termauk waris, sarat dengan pendapatpendapat yang mengarahkan pada pengalaman sosial mereka, walaupun ada perbedaan pendapat di sana-sini.

\section{Teori Tingkatan Kelas Ahli Waris}

Pendapat berbeda, dalam persoalan di atas, yang ditemukan adalah dikemukakan aț-Ṭābațabā'î. Menurut beliau saudara tidak dapat mewarisi selama ada keturunan (secara mutlak) dan orang tua (bapak maupun ibu). Karena anak dan orang tua sama hubungan kedekatannya, maka orang tua pun diberi hak menghijab kerabat garis sisi ---sama seperti anak. ${ }^{21}$ Pendapat ini, sebagaimana pendapat kalangan Syi'ah yang membagai ahli waris dalam tiga tingkatan yang antara tingkatan saling menghijab, 22 menempatkan posisi orang tua termasuk ibu lehih tinggi dari saudara.

Posisi saudara sebagai ahli waris nasabiyyah berada pada tingkatan kelas ke II bersama dengan eyang. Kelompok II ini termasuk juga di dalamnya keturunan saudara. Pada kelas I terdapat orang tua (ibu dan bapak), anak atau keturunan langsung. Sedangkan kelas III terdapat paman dan bibi pihak ayah, paman dan bibi dari pihak ibu orang yang meninggal, dan dari orang tuanya atau eyangnya, dan seterusnya. Dengan prinsip kelas ini, ahli waris pada kelas I menutupi ahli waris kelas II, demikian pula ahli waris kelas II menutupi ahli waris kelas III. Ahli waris pada kelompok I yang terdiri dari orang tua dan anak mewarisi secara bersama-sama dan tidak saling menutupi. ${ }^{23}$ Dengan keyakinan seperti inilah, saudara tidak

${ }^{21}$ Muhammad Husein aț-Ṭābațabā'̄̄, Al-Mīzān fi Tafsīr al-Qur'ān (Beirut: Mu'assasat al-'Alami, 1978), 212-3

${ }^{22}$ Bandingkan dengan sistem kewarisan Sunni. Kalangan Sunni membagai kelompok ahli waris secara prinsip menjadi tiga bagian juga, tetapi berdasarkan garis keutamaan, yaitu qur'anic heirs (zau alfurud,), agnate heirs ('Ashabah), dan Uterine Heirs (zau al-arham). Penjelasan ketiganya banyak tersebar dalam tulisan-tulisan hukum waris. Misalnya, A. D. Ajijola, The Concept of Family in Islam (New Delhi: Adam Publishers and Distributors, 2006), hlm. 159-89

23 A.A.A. Fyzee, Outlines of Muhammadan Law, cet. ke4 (London: Oxford University Press, 1974), hlm. 442; J N D Anderson, Islamic Law in the Moderen World (New York: New York University Press, 1959), hlm. 67-8; Di sinila secara umum terjadi perbedaan penting antara konsep kewarisan Syi'ah 
dapat mewarisi selama pewaris memiliki anak ataupun orang tua baik bapak maupun ibu (kelas I).

\section{Sistem Kekeluargaan}

Untuk meninjau hukum kewarisan ini kita harus mengamati bentukbentuk kemasyarakatan dan sistem-sistem kekeluargaan. Menurut ilmu antropologi sosial, pada garis besar ada 3 macam cara orang menentukan garis keturunan, yaitu pertama, orang menarik garis keturunannya ke atas hanya melalui bapaknya; bapak itu menarik garis keturunannya melalui bapaknya lagi dan begitulah seterusnya sampai kepada bapak asal, yang dipercayai sebagai asal yang menurunkan mereka; cara ini menurunkan sistem patrilineal. Kedua, orang menarik garis keturunannya ke atas hanya melalui ibunya; ibu itu menarik garis keturunannya melalui ibunya lagi dan begitulah seterusnya sampai kepada ibu asal yang dianggap asal yang menurunkan mereka; cara ini melahirkan sistem kekeluargaan matrilinial. Cara pertama dan kedua ini disebut sistem unilateral karena hanya menarik garis keturnan pada salah satu pihak saja. Ketiga, orang menarik garis keturunannya ke atas melalui bapaknya atau ibunya, demikian juga yang dilakukan bapak dan ibunya, dan demikianlah seterusnya; cara ini melahirkan sistem kekeluargaan bilateral. ${ }^{24}$ Jika di kroscekkan pada masyarakat Arab, dalam banyak tulisan, maka mereka menganut model sistem patrilinial asli yang banyak berpengaruh terhadap perkembangan sejarah patriarki sesudahnya di kawasan ini. ${ }^{25}$ Dengan demikian, bukanlah

dan Sunni, yaitu dalam dataran pendekatan yang digunakan. Sunni menggunakan ketentuan khusus dalam al-Qur'an yang dapat diaplikasikan dan mempengaruhi individu-individu yang disebut di dalamnya tanpa merubah hukum adat pra Islam dan penggunaan-penggunaannya. Sedangkan kewarisan Syi'ah menggunakan aturan khusus al-Qur'an hanya sebagai ilustri prinsip umum yang pokok di dalamnya. Mohammad Mustafa Ali Khan, Islamic Law of Inheritance: A New Approach (New Delhi: Kitab Bhavana, 1989), hlm. 173-4 hlm. 243-4

24 Anwar Harjono, Hukum Islam Keluasan dan Keadilannya (Jakarta: Bulan Bintang, 1968),

25 Nasruddin Umar, Argumen Kesetaraab Jender Perspektif al-Qur'an (Jakarta: Paramadina, 1999), hlm. 129 
hal yang mengejutkan ketika pendapat seperti mengutamakan pembagian Ayah dari pada saudara; mempertimbangkan penafsiran saudara pada kalālah pertama sebagai saudara seibu dan kalālah kedua sebagai saudara sekandung atau sebapak; mengutamakan hak waris kakek dari pada hak waris saudara, kita temukan.

Persoalan pertama di atas didasari oleh garis keutamaan antara ayah dan saudara. Persoalan kedua untuk menunjukan bahwa saudara seibu memiliki kedudukan lebih rendah dari saudara sekandung atau seayah dengan bukti bahwa saudara seibu menerima bagian warisan yang sama antara laki-laki dan perempuan, sedangkan saudara seayah atau sekandung memiliki bagian yang tidak berimbang antara pihak laki-laki dan perempuan. Persoalan ketiga adalah yang paling banyak diperbincangkan. Setidaknya kalangan Sunni lebih bersemangat mempertahankan kewarisan yang patrilinial dengan pokok-pokok pikiran sebagai berikut:

1. selalu memberikan kedudukan yang lebih baik dalam perolehan harta peninggalan kepada pihak laki-laki. Dalam hubungan ini termasuk juga perbandingan perolehan antara ibu dan bapak atas harta peninggalan anak.

2. urutan keutamaan berdasarkan 'așabah dan laki-laki. 'Așabah adalah anggota keluarga yang mempunyai hubungan darah sesamanya berdasarkan hubungan garis keturnan laki-laki.

3. istilah-istilah khusus mengenai kewarisan dalam al-Qur'an mungkin disamakan dengan istilah biasa dalam bahasa sehari-hari atau istilah hukum adat dalam masyarakat Arab. ${ }^{26}$

Namun, dalam kewarisan yang dikembangkan al-Qur'an, pada dasarnya, menurut Hazairin, bukanlah sistem patrilinial. Alasan kalangan

${ }^{26}$ Sajuti Thalib, Hukum Kewarian Islam..., hlm. 112 
Sunni masih mempertahankan sistem kekerabatan patrilinial dalam hukum waris karena "garis-garis hukum kekeluargaan, termasuk garisgaris hukum kewarisan dalam al-Qur'an, dipahami ahl as-sunnah wa aljama'ah hanya sebagai suatu penyimpangan dari hukum adat masyarakat Arab; suatu penyimpangan yang membawa perobahan-perobahan besar dalam hukum adat ini tidak disadari, bahwa garis-garis hukum al-Qur'an itu merombak sistem masyarakat Arab....pengertian 'așabah yang berurut kepada susunan masyarakat yang patrilinial tetap dipertahankannya, karena tidak menginsafi, bahwa al-Qur'an merombak masyarakat tersebut menjadi masyarakat bilateral." 27

\section{E. Kakek dan Saudara Sebagai Ahli Waris}

Selanjutnya, perbincangan tentang posisi saudara dalam hukum waris adalah ketika ia bersama dengan kakek. Apakah saudara terhijab oleh kakek atau tetap mendapatkan bagian waris. Ada dua pendapat yang berkembang tentang posisi saudara dalam kasus ini. Pertama, saudara tidak mendapatkan harta warisan ketika ada kakek karena kakek menutup hak saudara baik laki-laki maupun perempuan dalam ketiga hubungannya (saudara seayah, saudara sekandung, dan saudara seibu). Pendapat ini dipegang oleh Ibn Abbas, Abdullah bin Zubeir, Usman, Aisyah, Ubay bin Ka'ab, Mu'ad bin Jabal, Abu Musa dan lainnya yang kemudian diikuti oleh Abu Hanifah, al-Muzzani, Daud dan Ibn Munzir. Kedua, pendapat sebaliknya yang menyatakan bahwa kakek tidak menghijab saudara untuk mewarisi. Menurut pendapat yang kedua ini saudara hanya terhijab oleh anak laki-laki atau cucu laki-laki dan ayah. ${ }^{28}$ Pendapat ini dipegang oleh Ali, Zaid bin Tabit, Ibn Mas'ud yang kemudian diikuti oleh imam asy-Syafi'i, imam Ahmad, Abu Yusuf dan

${ }^{27}$ Hazairin, Hukum Waris Bilateral....., hlm. 75

${ }^{28}$ Amir Syarifuddin, Hukum Kewarisan Islam (Jakarta: Prenada Media, 205), hlm. 116 
Muhammad al-Syaibani dari kalangan Hanafiyyah, dan al-Auza'i. Di luar dua pendapat di atas, satu pendapat lain yang dipegang oleh mazhan Maliki adalah bahwa kakek hanya menghalangi saudara atau saudari seibu untuk mewarisi tetapi tidak untuk saudara sekandung atau seayah. ${ }^{29}$ Namun, pendapat terakhir ini tidak kita eksplorasi lebih jauh mengingat keyakinan kita bahwa al-Qur'an tidak membedakan antara jenis-jenis saudara dan saudari. Sedangkan kedua pendapat sebelumnya dapat dijelaskan lebih lanjut.

Pendapat yang pertama didasari pada hadis yang memerintahkan agar memberikan furud kepada yang berhak menerima dan selebihnya diberikan kepada pihak keluarga terdekat dari laki-laki dalam garis lakilaki. Dalam urutan kekerabatan kakek berada di atas saudara. Alasan lain dikemukan Ibn Qudamah. Ia memperluas pengertain “ayah" dalam alQur'an, yaitu mencakup pengertian "kakek". ${ }^{30}$ Dengan demikin, ia mengganti kedudukan Ayah. Pendapat yang kedua didasari pada argumentasi bahwa hak mewarisi saudara ditetapkan berdasarkan naș yang șarih dan tidak mungkin ia terhijab kecuali bila dinyatakan oleh nașs atau ijma'. Argumentasi lainnya adalah bahwa saudara memiliki kedudukan yang sama dalam faktor yang menyebabkan mereka mendapatkan warisan, yaitu dihubungkan dengan pewaris melalui perantara bapak sebagaimana kakek. Nampaknya, pendapat kedua ini dapat dijadikan pegangan sekalipun dalam perkembangannya pendapat ini justru mengalami pembahasan-pembahsan yang rumit. Jika memakai model kewarisan yang dipegang mazhab Syi' ah maka kakek akan terhijab jika ada salah satu orang tua pewaris.

${ }^{29}$ Ajijola, The Concept of Family in Islam..., hlm. 171

30 Ibn Qudamah, al-Muqhn̄̄ (Kairo: Maktab al-Qahiriyah, 1970), VI: 307-8; Di sisi lain, pendapat seperti ini juga ditemukan dalam pemikiran imam asy-Syafi' i. Bahkan baginya kakek menutupi saudara seibu untuk mendapatkan warisan. Lihat: Ringkasan Kitab al-Umm (2), edisi revisi, alih bahasa: Muhammad Yasir Abd. Muthalib (Jakarta: Pustaka Azzam, 2007), hlm. 182-3 


\section{F. Ahli Waris Primer dan Ahli Waris Sekunder ${ }^{31}$}

Posisi kewarisan saudara yang penting dibahas, selanjutnya, adalah kemungkinan saudara dapat mewarisi ketika ada anak perempuan. Jumhur ulama berpendapat bahwa saudara dapat mewarisi jika pewaris hanya memiliki anak perempuan. Hal ini didasari pada keyakinan bahwa anak perempuan tidak dapat menghijab saudara-saudari untuk mewarisi. Khusus untuk saudari, ia memiliki bagian 'așabah ma'al ghair bila bersamaan dengan anak perempuan atau cucu perempuan garis laki-laki. Pendapat ini di tolak oleh Ibn $\mathrm{Abbas}^{32}$ dan kita lebih sepakat untuk memegang pendapat Ibn Abbas yang tidak membedakan antara anak lakilaki dan perempuan dalam hal menghijab saudara. Tidak hanya itu berdasarkan kewarisan primer dan sekunder nampak jelas bahwa hanya saudara yang menduduki posisi ahli waris sekunderlah yang memiliki bagian yang sudah ditentukan, yaitu 1/6 atau 1/3.

Posisi saudara pada ayat kalālah pertama, sebagaiman telah disinggung dalam bagian sebelumnya, adalah sebagai ahli waris sekunder dimana ia menerima warisan bersamaan dengan ibu dan bapak. Sedangkan kalālah kedua menempatkan saudara pada posisi ahli waris primer dimana ahli waris sekunder tidak ada. Istilah ahli waris primer dan sekunder hanya berlaku pada ahli waris nasabiyyah, sedangkan ahli waris sababiyah dalam kondisi apapun tetap mewarisi.

Dalam penerapan teori ahli waris primer dan sekunder ini menghasilkan banyak perbedaan dalam penyelesaian kasus waris. Dalam kasus diatas, saudara mendapat bagian $1 / 6$ jika ia sendirian dan mendapatkan $1 / 3$ jika berjumlah dua orang atau lebih. ${ }^{33}$ Tidak ada

\footnotetext{
31 Terminologi ahli waris primer dan ahli sekunder diambil dari penjelasan David S.Power dalam Studies in Qur'an and Hadis..., hlm.95-102

${ }^{32}$ Fatchur Rahman, Ilmu Waris (Bandung: al-Ma'arif, 1971), hlm. 302-3

${ }^{33}$ Dalam ketentuan hukum waris yang berjalan, bagain 1/6 dan 1/3 ini untuk saudara seibu bila tidak bersama far'u dan ashu waris. Jika bersamaan, maka keduanya menghijab saudara tersebut. Bagain
} 
pembedaan antara laki-laki dan perempuan, termasuk jika keduanya lakilaki, keduanya perempuan atau satu orang laki-laki dan satu orang perempuan. Misalnya, seoarang laki-laki meninggal dunia dan ia meninggalkan istri, ibu, ayah, satu orang saudara laki-laki dan satu orang saudara perempuan (baik seibu maupun sekandung) sebagai ahli waris, maka istri akan mendapatkan $1 / 4$ karena tidak ada anak, ibu mendapat 1/6 karena ada saudara sebagai ahli waris lainnya, saudara laki-laki mendapat $1 / 6$, saudara perempuan mendapat $1 / 6$, atau keduanya bersekutu dalam $1 / 3$, sedangkan bagian ayah tidak ditentukan. Dengan demikian kita akan membagi bagian-bagian yang sudah ditentukan al-Qur'an dan selanjutnya menentukan bagian ayah. Untuk mempermudah pembagiannya kita mengunakan asal masalah 24, sehingga istri mendapat $1 / 4 \times 24=6$ bagian, ibu mendapat $1 / 6 \times 24=4$ bagian, saudara laki-laki dan saudara perempuan mendapatkan $1 / 3 \times 24=8$ bagian. Total semua harta yang telah terbagi adalah 18/24 atau senilai $75 \%$. Dengan demikian bagian ayah adalah $24-18=6$ bagian atau senilai $1 / 4$. Dari kasus ini ahli waris nasabiyyah sebagai ahli waris primer adalah bapak dan ibu. Keduanya memiliki bagian yang tidak sama, sedangkan saudara adalah ahli waris sekunder dengan bagian yang sama besar.

Berikut ini akan kita selesaikan kasus yang pada masa sahabat menjadi perdebatan, yaitu kausus Akdariyah. Pewaris meninggalkan harta dengan ahli warisnya suami, ibu, saudari kandung/tunggal ayah dan kakek. Terjadi silang pendapat dalam pembagiannya dan beberapa pendapat mengusulkan adanya 'aul,34 kecuali Abu Bakar yang menghijab saudari. $^{35}$ Namun, kita akan menyelesaikan pembagian ini dengan

ini juga ditentukan bagi saudari seayah yang bersamaan dengan saudari sekandung. Sedangkan bila terdapat saudara sekandung atau saudara seayah, maka kedudukannya menjadi ashoba ma'al ghoirihi.

${ }^{34}$ Aul dan Radd adalah adanya kelebihan dan kekurangan dalam saham-saham para ahli waris. Lihat: Fatchur Rahman, Ilmu Waris..., hlm. 409-29

${ }^{35}$ Berbagai penyelesaian yang sudah dilakukan dapat dilihat dalam: Ibid., hlm. 526-8 
memberikan bagian suami $1 / 2$, ibu 1/6 karena ada saudara perempuan, satu orang saudara perempuan bagiannya 1/6 dan kakek bagianya tidak ditentukan. Dengan demikian, suami mendapatkan $1 / 2 \times 6=3$ bagian atau $50 \%$, ibu mendapatkan $1 / 6 \times 6=1$ bagian, saudari perempuan mendapatkan $1 / 6 \times 6=1$ bagian, total harta yang dibagikan adalah 5 bagian. Maka sisa harta adalah 1 bagian menjadi bagian kakek. Dalam kondisi ini kakek tidak bisa ditempatkan sebagai ahli waris primer karena ada ibu. Ibulah yang menjadi ahli waris primer. Sedangkan saudara dan kakek menjadi ahli waris sekunder yang bagiannya sama. Seandainya harta yang ditinggalkan berupa uang senilai 1.500.000, maka suami mendapatkan 750.000, ibu mendapatkan 150.000, dan saudari perempuan mendapat 150.000 dan kakek mendapatkan 150.000. Dengan pembagian ini kita tidak mengenal adanya rad atau 'aul.

Selanjutnya, pada kasus kalālah kedua pembagain waris ditetapkan berdasarkan ketentuan ahli waris primer. Apabila ahli waris itu saudara perempuan satu orang maka bagian warisnya adalah $1 / 2$, bila berjumlah dua orang atau lebih maka bagian warisnya adalah $2 / 3$, dan apabila mereka berupa laki-laki dan perempuan dalam jumlah yang banyak maka untuk satu orang saudara laki-laki semisal bagian dua saudara perempuan. Model pendistribusian ini sama seperti pembagian harta kepada anak-anak.

Bagian-bagian pembagian harta pada anak-anak pewaris yang Allah tentukan adalah bagian perempuan, sedangkan bagian laki-laki tidak ditentukan secara jelas. Ketentuan yang ada dalam al-Qur'an meliputi ketentuan jika anak perempuan berjumlah lebih dari dua orang maka ia mendapatkan bagian 2/3, jika anak perempuan itu satu orang maka ia mendapatkan $1 / 2$, dan jika anak perempuan itu berjumlah dua orang maka ia mendapatkan bagian semisal satu orang anak laki-laki. Analisa menarik dilakukan oleh Syahrūr tentang pembacaan ayat ini. 
Menurutnya keadilan pembagaian sama rata tidak mungkin tercapai kecuali dalam dua kasus saja, yaitu jumlah anak laki-laki sama dengan jumlah anak perempuan atau himpunan laki-laki sama dengan himpunan perempuan (1 laki-laki +1 perempuan, 2 laki-laki +2 perempuan, 3 lakilaki +3 perempuan, dan seterusnya, dalam hal ini jumlah anak laki-laki dan perempuan berimbang), dan keseluruhan anak terdiri dari laki-laki tanpa perempuan atau keseluruhan perempuan tanpa laki-laki. Dalam

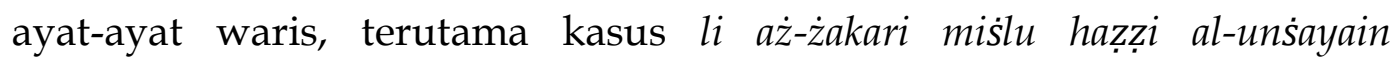
menunjukan bahwa penyebutan variabel laki-laki didahulukan karena berfungsi sebagai pengikut dan variabel perempuan disebutkan dengan jumlah satu dan seterusnya karena posisinya sebagai pe-ubah. ${ }^{36}$ Dengan demikian, kemungkinan logis untuk ayat tersebut adalah bahwa perempuan merupakan dasar dalam pembagian waris, sedangkan lakilaki mengikuti ketentuan yang dihasilaknnya. Dari pembacaan ini, kemudian ditentukanlah batasan-batasan Allah.

Relevansi dari pembacaan di atas ketika Allah menyebutkan bagian anak perempuan, maka secara otomatis disampingnya ada anak laki-laki dalam jumlah berapapaun. Jika jumlah anak tersbut hanya satu baik lakilaki maupun perempuan, harta tersebut akan diambil semua setelah pembagaian kepada ahli waris yang disebutkan al-Qur'an semisal istri atau suami, ibu dan bapak. Batasan yang tidak seimbang pada bagian anak hanya berlaku ketika jumlah anak tersebut tiga orang, yaitu satu anak laki-laki dan dua anak perempuan, sehingga anak laki-laki mendaptkan setangah dan dua anak perempuan mendapatkan setengah.

Kembali pada kalālah kedua, dalam kasus saudara sebagai ahli waris primer, saudara laki-laki hanya disebutkan dalam kasus berjumlah banyak sedangkan dalam kondisi satu orang atau dua tidak disebutkan.

36 Syahrūr, Nahw Ușul Jadidah ..., hlm. 240 
Sama halnya dengan ketetapan pada anak, ketetapan pada saudara ditekankan pada pembagaian waris untuk perempuan. Perbedaannya jika aturan pada anak perempuan disebutkan sejak semula perbandingannya dengan anak laki-laki, sedangkan ketentuan saudara perempuan disebutkan perbandingannya jika brjumlah banyak saja. Contoh kasus untuk kalālah kedua, misalnya seseorang meninggal dunia dengan meninggalkan ahli warisnya, yaitu istri, dua orang saudara perempuan, dan satu saudara laki-laki. Dalam kasus ini istri mengambil bagian 1/4 karena tidak ada anak, dan dua orang sauadara beserta satu saudara lakilaki mendapatkan asbobah bil ghairihi.

Istri mendapatkan 25\%, dua saudara-saudara mengambil sisanya dengan ketentuan mengikuti rumusah ahli waris primer dengan bagian yang tidak sama antara laki-laki dan perempuan.. Jika harta yang ditinggalkan tersebut berupa uang tunai senilai Rp.1000.000.000,- maka istri akan mendapatkan Rp. 25.000.000,- dan saudara-saudara tersebut mendapatkan Rp.75.000.000,- dengan bagian dua saudara perempuan masing-masing mendapat Rp. 18.750.000,- dan satu saudara laki-laki mendapatkan Rp. 37.500.000,--

Asy-Syafi'i ketika mengemukakan cara pembagain warisan untuk satu orang saudara perempuan yang mana ia mewariskan harta tanpa ada ahli waris lainnya adalah dengan memberikan $1 / 2$ sebagai bagain yang Allah tetapkan. Sisa hartanya dikembalikan kepada saudara perempuan tersebut juga berdasarkan perhubungan sekandung (zawi al-arham). ${ }^{37}$

Berdasarkan penjelasan-penjelasan di atas, relevansi pemahaman kalālah terhadap hukum kewarisan Islam adalah menghilangkan dikotomi antara saudara-saudara dalam menerima harta warisan, karena perbedaan dua ayat kalālah dalam al-Qur'an bukan menunjukan adanya dikotomi itu

${ }^{37}$ Muhammad Idris asy-Syafi'i, Ar-Risalah li al-Imam al-Muțalibi Muhammad ibn Idris asySyafi'I (ttp.: Dār al-Fikr, t.t), hlm. 586-7 
tetapi lebih pada pembedaan kedudukan saudara-saudara sebagai ahli waris di samping ahli waris lainnya (Ahli Waris Primer atau Sekunder)

\section{G. Kesimpulan}

Kedudukan saudara sebagai ahli waris harus diposisikan ulang sesuai dengan realitas yang ada. Tidak ada kebutuhan signifikan dalam membedakan saudara sekandung, seayah atau seibu melainkan hanya persoalan konstruk sosial atau budaya an sich. Saudara sejatinya harus dalam kedudukan sejajar sebagai ahli waris tanpa membuat dikotomi, kecuali saudara tiri yang memang tidak masuk dalam golongan ahli waris. Oleh karena itu pembacaan ulang terhadap ayat kalalah menghasilkan cara pemahaman baru dalam hukum waris Islam, yaitu menepatkan saudara sebagai ahli waris sekunder jika terdapat ahi waris kelas 1 dan menjadikan ahli waris primer dalam kondisi tidak ada ahli waris kecuali golongan saudara. 


\section{DAFTAR PUSTAKA}

Abubakar, Al Yasa, Ahli Waris Sepertalian Darah: Kajian Perbandingan Terhadap Penalaran Hazairin dan Penalaran Fikih Mazhab, Jakarta: INIS, 1998.

Ajijola, A. D., The Concept of Family in Islam, New Delhi: Adam Publishers and Distributors, 2006.

Andalusī, Muhammad Yusuf Abu Ḥayyān al-, Al-Baḥr al-Muḥit, cet.ke.2, Beirut: Dār al-Fikr, 1978.

Anderson, J N D, Islamic Law in the Moderen World, New York: New York University Press, 1959.

Arabi, Abī Bakr Muhammad bin Abdullah Ibn, Ahkām al-Qur'ān, tahqiq: Ali Muhammad al-Bajawī, ttp.: tnp., 1967.

Boulata, Issa J., Dekonstruksi Tradisi: Gelar Pemikiran Arab Islam, alih bahasa: Imam Khoiri, cet.1, Yogyakarta: Lkis, 2001.

Fyzee, A.A.A., Outlines of Muhammadan Law, cet. ke4, London: Oxford University Press, 1974.

Harjono, Anwar, Hukum Islam Keluasan dan Keadilannya, Jakarta: Bulan Bintang, 1968.

Hazairin, Hukum Kewarisan Bilateral Menurut al-Qur'an dan Hadis, Jakarta: Tintamas, 1982.

Juandi, "Pemahaman dan Pemaknaan Kalalah dalam Historisitas Hukum Kewarisan Islam" dalam Asy-Syari'ah: Jurnal Ilmu Syari'ah dan Perbankan Islam, Vol.1, no.1 Desember 2013 STAIN Syaikh Abdurrahman Siddik.

Khan, Mohammad Mustafa Ali, Islamic Law of Inheritance: A New Approach, New Delhi: Kitab Bhavana, 1989.

Khān, Șadiq Hasan, Fatḥ al-Bayān fii Maqāṣid al-Qur'ān, ttp.: tnp., t.t.

Kholaf, Abdul Wahab, Ilmu Ushul Fikih: Kaidah Hukum Islam (terj. Faiz al Muttaqin), Jakarta: Pustaka Amani, 2003.

Muchtar, Kamal, dkk, Ushul Fikih Jilid 1, Jakarta: Dhana Bakti Wakaf, 1995 
Power, David S., Studies in Qur'an and Hadis: The Formation of the Islamic Law of inheritance, Barkeley: University of California Press, 1986.

Power, David S."The Islamic Law of Inheritance Reconsidered: a New Reading of Q. 4:12B", dalam Studia Islamica No. 1-70 thn. 1953-1989 (Paris: G.P Maisonneuve-Larose, 1982), XXVIII.

Qudamah, Ibn, al-Muqhnī , Kairo: Maktab al-Qahiriyah, 1970

Qurțubi, Muhammad bin Ahmad Abi Abdullah al-Anshori al-, Al-Jāmi' li ahkām al-Qur'ān, cet. ke-2, ttp: Dār al-Kitāb al-'Arabi, 1967.

Quțub, Sayyid, Fi Zhilal al-Qur'an, Beirut: Dār Ihya', 1971.

Rahman, Fatchur, Ilmu Waris, Bandung: al-Ma'arif, 1971.

Riḍa, Muḥammad Rasyid, Tafsìr al-Qur'an al-Hakìm al-Masyhūr bi Tafsìr alManār, Beirut: Dār al-Kutub al-Ilmiyah, 1999.

Syafi'i, Muhammad Idris asy-, Ar-Risalah li al-Imam al-Muțalibi Muhammad ibn Idris asy-Syafi'I, ttp.: Dār al-Fikr, t.t.

Syaḥrūr, Muḥammad, Naḥw Ușul Jadidah lil Figh al-Islāmī Figh al-Mar'ah (alWașiyah, al-Ir's, al-Qawāmah, at-Ta'addadiyah, al-Libās), Damaskus: Al-Ahali lil-Tiba'ah Wa an-Nașr wa at-Tauzi, 2000.

Syarifuddin, Amir, Hukum Kewarisan Islam, Jakarta: Prenada Media, 2005.

Țabari, Abu Ja'far Muhammad Ibn Jarir at-, Jami' al-Bayan an Ta'wil ay al-Qur'ān, Bairut: Dār al-Fikr, t.t.

Ṭābațabā'ì, Muhammad Husein aț-, Al-Mīzān fi Tafsìr al-Qur'ān, Beirut: Mu' assasat al-'Alami, 1978.

Thalib, Sajuti, Hukum Kewarian Islam di Indonesia, cet.ke-8, Jakarta: Sinar Grafika, 2004.

Umar, Nasruddin, Argumen Kesetaraab Jender Perspektif al-Qur'an, Jakarta: Paramadina, 1999.

Zahrah, Muhammad Abu, Ahkām at-Tirkāt wa al-Mawāris, al-Qāhirah: Dār alFikr al-'Arabī, 1963. 